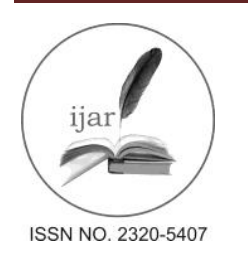

Journal homepage: http://www.journalijar.com

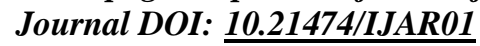

INTERNATIONAL JOURNAL

OF ADVANCED RESEARCH

RESEARCH ARTICLE

\title{
APPLICATION AND EFFECTIVENESS OF FINANCIAL CONTROL TECHNIQUES IN INDIAN BANKS- AN EMPIRICAL EVIDENCE.
}

\author{
Jasmine kaur ${ }^{1}$, DR. Shailinder sekhon ${ }^{2}$. \\ 1. Research Scholar, School of Management Studies, Punjabi University Patiala, Punjab, India, 08283820311. \\ 2. Department of Distance Education, Punjabi University Patiala, Punjab, India,09780637969.
}

\section{Manuscript Info}

Manuscript History:

Received: 15 April 2016

Final Accepted: 29 May 2016

Published Online: June 2016

Key words:

Financial control, Public sector banks, private sector banks,

Profitability and Mismanagement.

*Corresponding Author

Jasmine kaur.

\begin{abstract}
A sound system of financial control contributes to safeguarding the stakeholders' investment and the institutions assets. Further financial control also contribute to the safeguarding of assets, including the prevention and detection of fraud. Half tied financial control is a virus affecting banking sector. It affects liquidity and profitability, in addition posing threat on quality of asset and survival of banks. The intent of the research paper is to analyse the application of financial control techniques and to check their effectiveness with regard to their application in Indian banking sector. The study is pursued on the data collected through questionnaire at the 10 public and private sector banks from 8 managerial level bankers from each bank. The data has been used to analyze by percentage analysis, mann-whitney test and the correlation value. The importance of analyzing these techniques is to check the control systems applied in Indian banking sector. The application and the effectiveness of financial control techniques are distinctively analyzed for public and private sector banks.
\end{abstract}

\section{Introduction:-}

The intent of the research paper is to analyse the application of financial control techniques and to check their effectiveness with regard to their application in Indian banking sector. Since, The financial sector of any economy, with banking sector at its core, plays an integral part in its development, growth and progress. Thomas (1995) opined that the banks are not merely dealers in money but are in fact dealers in development. Economists have expressed a variety of opinions on the effectiveness of banking systems in promoting and facilitating economic development. Today, the bank has shifted from brick model to click model. Similarly, banks in India have played a pivotal role in mobilisation of savings and have helped in stimulating the economic development.

Financial control is fairly widely used both in literature and in speeches, yet no comprehensive definition of the term appears to exist anywhere (Breda, 1979). Breda (1979) defines financial control as (a) a set of related dollar denominated version model. Thus, the Financial Control function includes analyzing financial management instruments as well as the associated systems. But it is not merely financial accounting model or management accounting model. Here, financial accounting model includes numbers like increase in net income, net profits, net worth etc. Second model i.e. management accounting model includes budgets and budgeting process. Breda (1979) argued that financial control system is indeed separate from financial accounting and management accounting systems. It has some more to do over and above financial accounting and management accounting as aptly opined by BCorporation.net. BCorporation.net (2015) defines financial controls as the means by which an organization's resources are directed, monitored, and measured.

\section{Importance of Financial Control:-}

A sound system of financial control contributes to safeguarding the stakeholders' investment and the institutions assets. Further financial control also contribute to the safeguarding of assets, including the prevention and detection 
of fraud. Moreover, the financial control is being explained by ACCA (2010) as the control function of the financial manager becomes relevant for funding which has been raised. Are the various activities of the organization meeting its objectives? Are assets being used efficiently? To answer these questions, the financial manager may compare data on actual performance with forecast performance. Forecast data will have been prepared in the light of past performance (historical data) modified to reflect expected future changes. Future changes may include the effects of economic development, for example an economic recovery leading to a forecast upturn in revenues (Nkuah, J.K., Tanyeh, J.P. and Asante, J., 2013).

Walters and Dunn (2001) stated that, obtaining sufficient knowledge of the internal financial controls, both information technology (IT) controls and application controls are needed to facilitate the determination of the audit strategy and the carrying out of subsequent steps. Control Environment is the attitudes, abilities, awareness and actions of client personnel and particularly management in relation to control. Financial controls activities are the policies and procedures that help ensure management directives are carried out. Financial controls are all the policies and procedures adopted by the directors and management of all entity to assist in achieving their objective of ensuring as far as practicable, the orderly and sufficient conduct of its business, including adherence to internal policies, the safe guarding of assets, the prevention and detection of fraud and error, the accuracy and completeness of the accountancy records and the timely preparation of reliable financial information (Walters and Dunn, 2001). Thus, it can be said that financial control comprises of financial accounting numbers, budgets and budgeting, internal audits, risk mitigation techniques, human being involved, processes, information system, policies and procedures, decision making techniques etc. Particularly, in case of banking sector, financial control covers all the Bank's activities whose data streams have an important impact on its financial position, such as credit risk, performance indicators, information and management systems, the administrative budget, ALM and market risks.

\section{Literature Review:-}

The study of financial control is an emergent concept in all the financial institutions. The importance of the subject is also highlighted from the review of existing literature. With respect to financial control, Mafiana (2013) opined that a study of relationship between internal control effectiveness and financial performance in the Nigerian banking industry can help in avoiding failures. Similarly, Sofiah, Aini, Ruhanita and Noradiva (2013) provided evidence of accounting outsourcing practices in Malaysia and the management control strategies undertaken by these practicing firms to mitigate inherent risks. Ahmed Arif Ahmed Nauman Anees (2012) examined liquidity risk in Pakistani banks and evaluate the effect on banks' profitability. Hsiu, Hsun and Ying (2007) found that rather than leading to improved profitability, Chinese banks' efforts to develop non-traditional banking business actually had a negative impact on the ROA. Jensen and Payne (2003) found that managers of organizations establish control systems to reduce the agency costs inherent in those organizations. Jill M. D'Aquila (1998) highlighted that there were some reasons for concern about fraudulent financial reporting. Uche Chibuike (1998) related the bank's policy changes and bad debt problem. Lowe,E.A. (1994) felt the need of integrating accounting control systems with management control systems. Particularly in case of India Mahanta and Kakati (2011) found presence of weaknesses in process of the existing credit appraisal is a major cause of accounts turning into bad loans. Mallick and Sarkar et. al. (2010) found that NPAs (as a ratio of loans and advances) were significantly sticky and did not seem to have spiraled out of control over the 1990s. Uppal and Kaur (2009) found that in today's scenario, major problem of all the banks was how best to utilize their funds to earn maximum income with the reduction in costs so as to compete and survive in the emerging global competitive environment. As evident, only few studies have been conducted considering different different parameters of financial control e:g NPAs, ROA and audit. Thus study attempts to analyze the financial control systems using variables like CAMEL Model, Budgetary control, NPA Management, Financial statement analysis, Financial reporting, Internal Audit, External Audit and Basel guidelines/norms etc .

\section{Research Methodology:-}

The present study is confined to Indian banking sector only. Out of the various types of controls like Administrative, Financial, Operational and Personnel etc, this study focused on financial control only. The study is based on Primary data. For the purpose of collection of primary data sampling includes 8 managerial level bankers from each public and private sector banks. In total 20 banks( i.e 10 private sector and 10 public sector banks ) are selected from the based on market capitalization as on 31 march 2009. The list of banks as per Nifty PSU Bank Index and Nifty Private Bank Index on the basis of market capitalisation 31 march 2009 is as below: 
Table No 1.1:- List of Banks.

\begin{tabular}{|c|c|c|c|}
\hline Sr. No. & Name of the Bank & Sr. No. & Name of the Bank \\
\hline \multicolumn{2}{|c|}{ PUBLIC SECTOR BANKS } & \multicolumn{2}{c|}{ PRIVATE SECTOR BANKS } \\
\hline 1 & State Bank of India & 1 & ICICI Bank \\
\hline 2 & Punjab National Bank & 2 & HDFC Bank \\
\hline 3 & Bank of India & 3 & Kotak Mahindra Bank \\
\hline 4 & Bank of Baroda & 4 & ING Vasya Bank \\
\hline 5 & Canara Bank & 5 & Yes Bank \\
\hline 6 & Union Bank & 6 & J\&K Bank \\
\hline 7 & Indian Bank & 7 & Indusind Bank \\
\hline 8 & Allahabad Bank & 8 & Karur Vasya Bank \\
\hline 9 & IDBI Bank & 9 & 10 \\
\hline
\end{tabular}

For the purpose of study, the data was collected and was evaluated in SPSS and the data was found to non-normally distributed.

Objectives are the vital element of the study. Broadly the study aims at determining financial control practices being adopted in various functional areas of Indian banks to improve their performance and specifically objectives of the study were as follows:-

* To study and evaluate the financial control systems in selected banks.

* To evaluate the effectiveness of financial control techniques.

\section{Findings and Conclusions:-}

The following findings were the outcome of the research work as depicted in the tables below:

Time frame of applicability of Financial Control techniques:-

Table 1.2 here highlights the responses of the selected sample managers regarding time frame of applicability of financial control techniques. 
Table 1.2:- Time frame of applicability of Financial Control techniques.

\begin{tabular}{|c|c|c|c|c|c|c|c|}
\hline \multirow[b]{2}{*}{$\begin{array}{l}\text { Financial control } \\
\text { techniques }\end{array}$} & \multicolumn{7}{|c|}{ Time frame of applicability of techniques } \\
\hline & 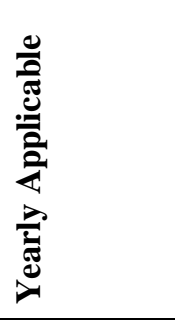 & 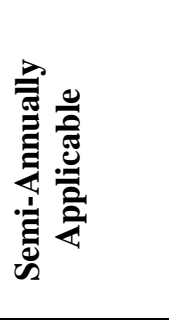 & 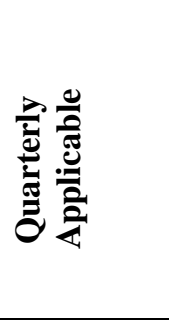 & 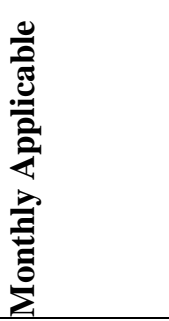 & 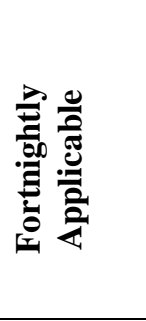 & 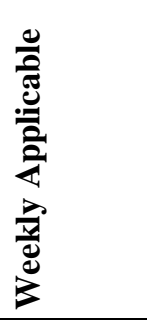 & 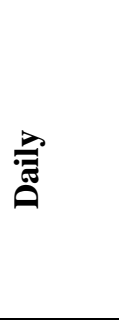 \\
\hline Target costing & $\begin{array}{c}32 \\
(20)\end{array}$ & $\begin{array}{c}2 \\
(1.25) \\
\end{array}$ & $76(47.50)$ & $42(26.25)$ & $\begin{array}{c}0 \\
(0)\end{array}$ & $\begin{array}{c}8 \\
(5) \\
\end{array}$ & $0(0)$ \\
\hline CAMEL Model & $\begin{array}{c}60 \\
(37.5) \\
\end{array}$ & $56(35)$ & $18(11.25)$ & $\begin{array}{c}10 \\
(6.25)\end{array}$ & $\begin{array}{c}16 \\
(10)\end{array}$ & $0(0)$ & $0(0)$ \\
\hline $\begin{array}{l}\text { Action profit linkage } \\
\text { model }\end{array}$ & $\begin{array}{c}84 \\
(52.5) \\
\end{array}$ & $0(0)$ & $50(31.25)$ & $18(11.25)$ & $0(0)$ & $0(0)$ & $8(5)$ \\
\hline Budgetary control & $\begin{array}{c}72 \\
(45)\end{array}$ & $\begin{array}{c}0 \\
(0)\end{array}$ & $60(37.50)$ & $\begin{array}{c}28 \\
(17.50)\end{array}$ & $0(0)$ & $0(0)$ & $0(0)$ \\
\hline Asset liability management & $\begin{array}{c}12 \\
(7.5) \\
\end{array}$ & $\begin{array}{c}16 \\
(10) \\
\end{array}$ & $66(41.25)$ & $\begin{array}{c}26 \\
(16.25) \\
\end{array}$ & $8(5)$ & $32(20)$ & $0(0)$ \\
\hline NPA Management & $14(8.75)$ & $\begin{array}{c}0 \\
(0) \\
\end{array}$ & $66(41.25)$ & $14(8.75)$ & $0 \quad(0)$ & $\begin{array}{c}66 \\
(41.25) \\
\end{array}$ & $0(0)$ \\
\hline Business per employee & $48(30)$ & $8(5)$ & $48(30)$ & $32(20)$ & $0(0)$ & $16(10)$ & $8(5)$ \\
\hline $\begin{array}{l}\text { Financial statement } \\
\text { analysis }\end{array}$ & $10(6.25)$ & $0(0)$ & $90(56.25)$ & $20(12.5)$ & $0(0)$ & $40(25)$ & $0(0)$ \\
\hline $\begin{array}{l}\text { Liquidity management by } \\
\text { call money market /CP's/ } \\
\text { CD's/ Treasury Bills }\end{array}$ & $2(1.25)$ & $8(5)$ & $2(1.25)$ & $16(10)$ & $52(32.5)$ & $44(27.5)$ & $\begin{array}{c}36(22.5 \\
)\end{array}$ \\
\hline Anti Money laundering & $0(0)$ & $0(0)$ & $0(0)$ & $30(18.75)$ & $8(5)$ & $\begin{array}{c}114(71.2 \\
5)\end{array}$ & $8(5)$ \\
\hline Financial reporting & $0(0)$ & $0(0)$ & $8(5)$ & $78(48.75)$ & $8(5)$ & $\begin{array}{c}66(41.25 \\
)\end{array}$ & $0(0)$ \\
\hline Investment management & $8(5)$ & $8(5)$ & $24(15)$ & $34(21.25)$ & $0(0)$ & $\begin{array}{c}86(53.75 \\
)\end{array}$ & $0(0)$ \\
\hline Tax Planning & $0(0)$ & (0) & $72(45)$ & $30(18.75)$ & $0(0)$ & $\begin{array}{c}58(36.25 \\
)\end{array}$ & $0(0)$ \\
\hline Priority sector lending & $32(20)$ & $(0)$ & $64(40)$ & $40(25)$ & $8(5)$ & $14(8.75)$ & $2(1.25)$ \\
\hline Internal Audit & $134(83.75)$ & $(0)$ & $10(6.25)$ & $8(5)$ & $0(0)$ & $8(5)$ & $0(0)$ \\
\hline External Audit & $138(86.25)$ & $(0)$ & $0(0)$ & $16(10)$ & $0(0)$ & $6(3.75)$ & $0(0)$ \\
\hline Basel guidelines/ norms & $4(2.5)$ & (0) & $32(20)$ & $0(0)$ & $24(15)$ & $\begin{array}{c}82(51.25 \\
)\end{array}$ & $\begin{array}{c}18(11.2 \\
5)\end{array}$ \\
\hline
\end{tabular}

Note: The figures provided in parenthesis denote percentages

The table shows financial control techniques; External audit, Internal audit, CAMEL model and Action profit linkage model are examined by majority as yearly and semi annually applicable. Financial control techniques those identified by majority of respondents viz-a-viz target costing, financial statement analysis, priority sector lending, tax planning, asset liability management, budgetary control, financial reporting, NPA management and business per employee applicable on quarterly and monthly basis. Maximum responses of bankers for liquidity management, anti money laundering, Basel guidelines/norms and investment management were recorded on fortnightly, weekly and daily basis. Hence it can be concluded that all the bankers were aware about the application of financial control techniques on the basis of time frame. Further for in-depth knowledge for the application of the financial control indicators in selected public and private sector banks is analyzed. Table 1.3 depicts the test statistics for time frame of application of financial control techniques. 
Table 1.3:- Time frame of applicability of Financial Control techniques in Public Sector Banks and Private Sector Banks

\begin{tabular}{|c|c|c|c|c|}
\hline \multicolumn{5}{|c|}{ Test Statistics $^{\text {a }}$} \\
\hline & Mann-Whitney U & Wilcoxon W & $\mathrm{Z}$ & $\begin{array}{l}\text { Asymp. Sig. (2- } \\
\text { tailed) }\end{array}$ \\
\hline Target costing & 538.000 & 1358.000 & -2.708 & $.007^{*}$ \\
\hline CAMEL Model & 482.000 & 1302.000 & -3.222 & $.001^{*}$ \\
\hline Action profit linkage model & 392.000 & 1212.000 & -4.327 & $.000^{*}$ \\
\hline Budgetary control & 668.000 & 1488.000 & -1.377 & .169 \\
\hline Asset liability management & 674.000 & 1494.000 & -1.267 & .205 \\
\hline NPA Management & 420.000 & 1240.000 & -3.947 & $.000^{*}$ \\
\hline Business per employee & 152.000 & 972.000 & -6.442 & $.000^{*}$ \\
\hline Financial statement analysis & 670.000 & 1490.000 & -1.395 & .163 \\
\hline $\begin{array}{l}\text { Liquidity management by call } \\
\text { money market /CP's/ CD's/ } \\
\text { Treasury Bills }\end{array}$ & 716.000 & 1536.000 & -.837 & .403 \\
\hline Anti Money laundering & 660.000 & 1480.000 & -1.695 & .090 \\
\hline Financial reporting & 780.000 & 1600.000 & -.213 & .831 \\
\hline Investment management & 526.000 & 1346.000 & -2.891 & $.004^{*}$ \\
\hline Tax Planning & 694.000 & 1514.000 & -1.103 & .270 \\
\hline Priority sector lending & 678.000 & 1498.000 & -1.229 & .219 \\
\hline Internal Audit & 754.000 & 1574.000 & -.689 & .491 \\
\hline External Audit & 712.000 & 1532.000 & -1.416 & .157 \\
\hline Basel guidelines/ norms & 522.000 & 1342.000 & -2.897 & $.004^{*}$ \\
\hline a. Grouping Variable: Sector & & & & \\
\hline
\end{tabular}

*represents the significant result

$\mathbf{N}=\mathbf{1 6 0}$

Data shows the result of the Mann-Whitney and Wilcoxon test. As per table there is statistically significant difference (at 99\% confidence level) among private and public sector banks in the frequency of the financial control techniques like Camel Model, Action linkage profit model, NPA management and business per employee. Negative $\mathrm{Z}$ values suggest that private sector banks adopt these frequently with regards to time frame, in other words private sector banks review their control measures from time to time, so as to perform exceptionally good. It can be concluded that these financial control techniques are differently adopted in selected Indian banks.

So, a review about the time frame of application of financial control techniques we need to review the effectiveness of financial control techniques, so that the bankers are in a appropriate situation to review /revise the application of these techniques in accordance to time. Public sector banks should improve the application of financial control measures periodically.

\section{Effectiveness of Financial Control techniques:-}

All the twenty sampled banks, apply the financial control techniques, other than application of these techniques, one of the objective behind it is; the effectiveness (in form of performance improvement) by application of these techniques. Table no.1.4 depicts Effectiveness of Financial Control techniques in Indian banks. 
Table 1.4:- Effectiveness of Financial Control techniques in selected Indian Banks.

\begin{tabular}{|l|l|l|l|l|l|}
\hline \multirow{2}{*}{ Financial Control techniques } & \multicolumn{5}{|c|}{ Level of effectiveness } \\
\cline { 2 - 5 } & Exceptional & \multicolumn{1}{|c|}{$\begin{array}{c}\text { Highly } \\
\text { Effective }\end{array}$} & \multicolumn{1}{|c|}{ Effective } & Inconsistent & Unsatisfactory \\
\hline Target costing & $4(2.5)$ & $68(42.5)$ & $84(52.5)$ & $4(2.5)$ & $0(0)$ \\
\hline CAMEL Model & $26(16.25)$ & $54(33.75)$ & $80(50)$ & $0(0)$ & $0(0)$ \\
\hline Action profit linkage model & $6(3.75)$ & $60(37.5)$ & $78(48.75)$ & $16(10)$ & $0(0)$ \\
\hline Budgetary control & $2(1.25)$ & $72(45)$ & $86(53.75)$ & $0(0)$ & $0(0)$ \\
\hline Asset liability management & $4(2.5)$ & $82(51.25)$ & $72(45)$ & $2(1.25)$ & $0(0)$ \\
\hline NPA Management & $4(2.5)$ & $116(72.50)$ & $32(20)$ & $8(5)$ & $0(0)$ \\
\hline Business per employee & $12(7.5)$ & $64(40)$ & $78(48.75)$ & $6(3.75)$ & $0(0)$ \\
\hline Financial statement analysis & $16(10)$ & $64(40)$ & $74(43.25)$ & $6(3.75)$ & $0(0)$ \\
\hline $\begin{array}{l}\text { Liquidity management by call } \\
\text { money market /CP's/ CD's/ }\end{array}$ & $8(5)$ & $66(41.25)$ & $80(50)$ & $6(3.75)$ & $0(0)$ \\
Treasury Bills & & & & \\
\hline Anti Money laundering & $4(2.5)$ & $88(55)$ & $64(40)$ & $4(2.5)$ & $0(0)$ \\
\hline Financial reporting & $6(3.75)$ & $94(58.75)$ & $56(35)$ & $4(2.5)$ & $0(0)$ \\
\hline Investment management & $14(8.75)$ & $92(57.5)$ & $50(31.25)$ & $4(2.5)$ & $0(0)$ \\
\hline Tax Planning & $16(10)$ & $70(43.75)$ & $74(46.25)$ & $0(0)$ & $0(0)$ \\
\hline Priority sector lending & $0(0)$ & $102(63.75)$ & $56(35)$ & $2(1.25)$ & $0(0)$ \\
\hline Internal Audit & $32(20)$ & $78(48.75)$ & $48(30)$ & $2(1.25)$ & $0(0)$ \\
\hline External Audit & $6(3.75)$ & $72(45)$ & $82(51.25)$ & $0(0)$ & $0(0)$ \\
\hline Basel guidelines/ norms & $6(3.75)$ & $92(57.5)$ & $62(38.75)$ & $0(0)$ & $0(0)$ \\
\hline Note: The figures & & \\
\hline
\end{tabular}

Note: The figures provided in parenthesis denote no. of percentages

The maximum bankers recorded following financial control techniques as effective at their banks 1)Priority sector lending 2) Budgetary control 3) Asset liability management4) External audit 5) Basel guidelines/norms 6) Target costing 7) Anti money laundering 8) Financial reporting 9) NPA Management 10) Liquidity management 11) Tax planning 12) Business per employee 13) Investment management14) Action profit linkage model 15) CAMEL model 16) Financial statement analysis 17) Internal audit. Few financial control techniques such as Internal audit and CAMEL model are considered by few (20-15\%) of the bankers as exceptionally effective in application.

Therefore it can be concluded that all the financial control techniques were effective in their application. A comprehensive view for selected public and private sector banks with regard to effectiveness of financial control techniques is analyzed. Data in table 1.5 depicts the test statistics for effectiveness for public and private sector banks. 
Table 1.5:- Mann Whitney analysis of public and private banks for financial control (effectiveness).

\begin{tabular}{|c|c|c|c|c|}
\hline \multicolumn{5}{|c|}{ Test Statistics $^{\mathrm{a}}$} \\
\hline & Mann-Whitney U & Wilcoxon W & $\mathrm{Z}$ & $\begin{array}{l}\text { Asymp. Sig. (2- } \\
\text { tailed) }\end{array}$ \\
\hline Target costing & 686.000 & 1506.000 & -1.243 & .214 \\
\hline CAMEL Model & 636.000 & 1456.000 & -1.730 & .084 \\
\hline Action profit linkage model & 600.500 & 1420.500 & -2.107 & $.035^{*}$ \\
\hline Budgetary control & 731.500 & 1551.500 & -.759 & .448 \\
\hline Asset liability management & 713.000 & 1533.000 & -.951 & .341 \\
\hline NPA Management & 753.000 & 1573.000 & -.579 & .563 \\
\hline Business per employee & 754.000 & 1574.000 & -.489 & .625 \\
\hline Financial statement analysis & 795.500 & 1615.500 & -.047 & .962 \\
\hline $\begin{array}{l}\text { Liquidity management by call } \\
\text { money market /CP's/ CD's/ } \\
\text { Treasury Bills }\end{array}$ & 646.500 & 1466.500 & -1.647 & .100 \\
\hline Anti Money laundering & 680.000 & 1500.000 & -1.316 & .188 \\
\hline Financial reporting & 712.500 & 1532.500 & -.969 & .332 \\
\hline Investment management & 680.500 & 1500.500 & -1.303 & .193 \\
\hline Tax Planning & 796.500 & 1616.500 & -.037 & .970 \\
\hline Priority sector lending & 748.000 & 1568.000 & -.599 & .549 \\
\hline Internal Audit & 624.500 & 1444.500 & -1.832 & .067 \\
\hline External Audit & 694.000 & 1514.000 & -1.159 & .246 \\
\hline Basel guidelines/ norms & 768.500 & 1588.500 & -.350 & .727 \\
\hline a. Grouping Variable: Sector & & & & \\
\hline
\end{tabular}

Table 1.5 shows the result of effectiveness of financial control techniques in both public and private sector banks. As evident from table except action profit linkage model, there is no significant difference in effectiveness of financial control techniques as adopted in public sector banks and private sector banks. Majority of the respondents from private sector banks treated it highly effective and exceptional as compared to public sector banks. It can be concluded that these financial control techniques have different level of effectiveness in selected Indian banks.

Thus tables 1.2 and 1.4 identify the need to check the application of each financial control techniques with regard to the effectiveness of each financial control techniques simultaneously by considering that there is efficient utilization of resources; whether, time, money, human resources involved in application of techniques and intelligent focus on the revenue generating techniques while considering their effectiveness.

Table 1.3 and 1.5 further distinguishes the application and effectiveness of financial control techniques on the basis of selected public and private sector banks. The objectives to enhance the sluggish performance of public sector banks with their private counterparts. Repetitive application of the financial control techniques can improve the efficiency and performance of public sector banks.

Although it is found that financial control techniques are applicable and found to be effective. To correlate the application of financial control techniques and their effectiveness co-relation between the both was calculated and the result is as follows

Formula: $\mathbf{r}=$

$$
\frac{\mathrm{N} \sum \mathrm{dxdy}-\sum \mathrm{dx} \sum \mathrm{dy}}{\sqrt{ }\left(\sum \mathrm{dx}^{2}-\left(\sum \mathrm{dx}\right)^{2}\right) * \sqrt{ }\left(\sum \mathrm{dy}^{2}-\left(\sum \mathrm{dy}\right)^{2}\right)}
$$

Where: $d x=$ applicability of financial control techniques $\mathrm{dy}=$ effectiveness of financial control techniques

$$
\mathbf{r}=\mathbf{- 0 . 0 2 7 3 8}
$$


Hence it is very evident from the co-relation value, that application of financial control techniques and their effectiveness are negatively correlated. That means neither the repetitive application of financial control technique increases the performance or deteriorates the performance. There is a repetitive need to alter the time frame of application of financial control techniques so as to increase the performance and result in positive value of correlation.

\section{Suggestions, scope for further research and conclusion:-}

1. Alteration in the time of application of financial control techniques, as per their effectiveness.

2. Fortnightly review should be done at bank level to avoid occurrence of wastage of human efforts towards application of financial control techniques.

3. Proper selection of borrowers \& follow ups required to get timely payment.

4. Special cell should be designated to review the procedural formats of each techniques, so that it is implemented in the desired direction.

\section{Scope for Further Research:-}

The present research has examined only few parameters to test the application of control theories, more parameters can be explored by rigorous study on parameters only.

\section{Conclusion:-}

Financial control systems being a principal part of the control systems, need to be focused and reviewed from time to time. So as to achieve the standards at every branch level. Thus, it has been observed that the application of financial control techniques are noticed and are found to be effective. Hence, commitment of the management with the effective implement of financial control techniques are suggested and revision of time frame of application of financial control needs to be done so as to enhance their effectiveness and reduce the repeated efforts towards the application of financial control techniques.

\section{References:-}

1. Ahmed Arif,Ahmed Nauman Anees, (2012), Liquidity risk and performance of banking system, Journal of Financial Regulation and Compliance, 20(2): 182 - 195.

2. Aquila, Jill M. D'(1998), Is the control environment related to financial reporting decisions?, Managerial Auditing Journal,13(8):472 - 478.

3. Balasubramaniam C.S., (2012), Non Performing Assets and Profitability of Commercial Banks in India: Assessment and Emerging Issues, Abhinav, National Monthly Refereed Journal of Research in Commerce \& Management, 1(7):41-52

4. BCorporation.net(2015), Implementing Financial Control, downloaded on May 2015 fromhttp://bimpactassessment.net/sites/all/themes/bcorp_impact/pdfs/B\%20Resources\%20\%20Implementing\%20Financial\%20Controls.pdf

5. Breda (1979), Towards the definition of Financial Control Systems, Working paper- Alfred P. Sloan School of Management: 1053-79

6. Collins, J., \& Jarver, R. (2000), Financial Information: The Vital Spark in the Small Enterprise Management, Paper Presented at the 23rd ISBA National Small Firms Policy and Research Conference, Small Firms: Adding the Spark, The Robert Gordon University, Aberdeen.

7. Frederick, D.(2001), Budgetary control, credit management, Abi/Inform Global:36-37.

8. Horngren, C.T. (1972), Cost Accounting; A Managerial Emphasis, $3^{\text {rd }}$ Edition, Englewood Cliffs, NJ, Prentice-Hall.

9. Hsiu-Ling Wu Chien-Hsun Chen Fang-Ying Shiu, (2007), The impact of financial development and bank characteristics on the operational performance of commercial banks in the Chinese transitional economy, Journal of Economic Studies, 34(5):401 - 414.

10. Jensen Kevan L. and Payne Jeff L.(2003), Management Trade-Offs of Internal Control and External Auditor Expertise, Auditing: A Journal of Practice \& Theory, 22(2):99-119. 
11. Mafiana, Enwelum Azu (2013) Examining the Relationships between Internal Control Effectiveness and Financial Performance in the Nigerian Banking Industry, Walden University, ProQuest, UMI Dissertations Publishing, Number:3553918.

12. Mahanta, Monoshree; Kakati, Munindra (2011), Effectiveness of Internal Rating Systems in Public Sector Banks of India, IUP Journal of Bank Management, X(3):7-33.

13. Mallick and Sarkar et. al.(2009)Dynamics of emerging India's banking sector assets: A simple Model, Journal of Asset Management, 11(1), 62-70.

14. Sharpe, W.F., Alexender, G.J. and Bailey, J.V. (1998), Investments: Prentice Hall of India Pvt. Ltd. New Delhi

15. Sofiah, Md Auzair, Aini Aman, Ruhanita Maelah, Rozita Amiruddin, Noradiva Hamzah (2013), Management control in accounting outsourcing services, Business Strategy Series, 14(2:3):43-49.

16. Tiwari, C. K. and Sontakke, R.(2013), Non Performing Assets - A Cause of Concern for Banks, ASM's International E-Journal of Ongoing Research in Management And IT, INCON 13-FIN-003

17. Uche Chibuike (1998), Accounting and control in Barclays Bank (DCO): the lending to Africans episode, Accounting, Business and Financial History,8(3): 239-260.

18. Uppal, R K and Juneja, A. (2013), New Trends in Productivity Parameters of Commercial Banking in India, Asian Journal of Research in Social Sciences and Humanities, 3(5): 258-287.

19. Walters, D. and Dunn, J. (2001), Student's Manual of Auditing, Thompson Learning, 6th Edition, London: 8:3.2-8:3.3 